\title{
Radical Menace, Reforming Hope: Scotland and English Religious Politics, 1586-1596
}

\author{
PAUL MCGINNIS \\ California State University, Sacramento \\ ARTHUR WILLIAMSON \\ California State University, Sacramento
}

Durant la fin des années 1580 et au début des années 1590, Jacques VI d'Écosse a adhéré sans équivoque à la Réforme. En se pénétrant de l'eschatologie protestante, en formant une alliance avec les presbytériens écossais, et en promouvant la réforme à la fois dans son royaume et à l'étranger, le roi fit de l'Écosse un phare de la Réforme. Simultanément, Jacques et ses nouveaux alliés - notamment Andrew Melville - ont vigoureusement favorisé une vision apocalyptique d'une Bretagne protestante unie. En conséquence, l'Écosse surgit comme jamais auparavant dans la politique religieuse tendue de l'Angleterre. Le débat sur la continuation de la Réforme s'est donc transformé en un débat au sujet de l'Écosse et de l'avenir post-élisabéthain anglais. Les conservateurs religieux anglais, tels que John Whitgift et Richard Bancroft, sérieusement alarmés, a lancé une campagne pour bloquer la succession Stuart ou au moins l'éventualité d'une union de la Bretagne. Cette campagne s'est manifestée dans les sermons et les traités de théologie et jusque dans la nouvelle littérature populaire de masse. Ce faisant, les conservateurs anglais ont créé des caricatures des écossais (en lien avec les caricatures des puritains, des ramistes et des juifs) qui ont par la suite déterminé et troublé les relations anglo-écossaise loin dans le dix-septième siècle et bien après.

\section{Radical Scotland}

The later 1580s saw Scotland's James VI striving to secure his Protestant reputation and to promote himself as a significant leader in the European confessional conflict. During these years the young king immersed himself in 
Protestant eschatology, and apocalyptic expectations suffused his thinking at this juncture more than at any other time in his life. Before the age of twenty, probably in early 1586, James prepared a line-by-line paraphrase of the Book of Revelation which gave the text a firmly Protestant reading-narrating the rise of the Roman Antichrist, as well as the present confrontation with the true faith whose triumph would culminate human experience in these latter days of the world. James's attitude was militant throughout. The Jesuits emerged as "the divels last brood," created by a desperate and declining satanic order. "A great number of nations who are not elect [i.e., the Catholic realms] are made drunk" by the false faith and now strain to destroy the truth. ${ }^{1}$ Certainly strident, certainly orthodox.

The king's studies issued in his more complex Ane Fruitfull Meditatioun on Revelation 20:7-10, written and published during the Armada crisis. On the frontispiece the author was presented not only as a "maist christiane King and synceir professour" but also as the "chief defender of the treuth." The volume offered a call to arms and an appeal for social solidarity, to "stand in our defense [as well as to] Incourage ane another to use lawfull resistance, and concur ane with another as warriouris in ane camp and citizenis of ane beloued citie." The tract proved radical in a variety of ways. Earlier in the decade Archbishop Patrick Adamson and James Stewart, Earl of Arran, presided over a conservative regime founded on episcopal hierarchy and derived from an exalted royal authority modelled grandly on the Roman emperor Constantine. The regime, it was widely believed, also flirted with Parma, Madrid, and the CounterReformation. That world had now vanished, and in the changed environment James nearly transformed himself into a citizen-king. At the same time any rapprochement with Catholicism became altogether unthinkable. The open Islamic enemy based in Constantinople made common cause with the covert, falsely-Christian enemy based in Rome. For however much the Turk and the Pope may have battled one another in the past, they had now reached "ane trewis amangis them" and stood "in odium terris, as did Herode and Pilate." More largely, Ane Fruitfull Meditatioun appears to be moving away from the imperial Protestant eschatology of John Foxe's Acts and Monuments (1563 and thereafter) towards the anti-imperial vision that John Napier of Merchiston would develop in A Plaine Discovery of the Whole Revelation (1593). Where Foxe saw Constantine as the archetypal agent of reform, Napier portrayed him as the man who launched the prophesied Antichrist. Anticipating Napier, James 
projected no such great reforming figure at the end of days. Further, in contrast to much earlier Protestant writing on the apocalypse and again anticipating Napier, James stressed God's "delyerance of his Kirk in this warld." "We see God hes promisit not onlie in the warld to cum, bot also in this warld to giue us victorie ouer them [Antichrist and the Catholic powers]." James anticipates Napier by shifting the focus away from simply identifying the historic Antichrist to emphasizing as well the final period of grace on earth before the end of time:

... efter the greit persecutioun and destructioun of the perseweris sall the day of iudgement follow. ... Bot in how short space it sall follow, that is onlie knawin unto God. Onlie thir far ar we certane, that in that last estait without ony ma generall mutatiounis the warld sall remane till the consummatioun $^{4}$

There would be an indeterminate period of triumph and latter-day glory at the conclusion of history, and Napier's great work followed on to block out the prophetic future that the king had declared. Both mark a shift toward the future-oriented apocalyptic that would characterize British eschatological exegesis during the 1590s. Even the titles of the two works sound oddly similar: Napier presented a "plaine discovery," while James's meditation offered "ane plane and facill expositioun."

Ane Fruitfull Meditatioun proved a notable success, quickly reaching a European audience. A French edition appeared in the following year at La Rochelle. Latin translations were later published at Basle, Halle, and Jena, and a Dutch version would also see print. Only subsequently did the best-selling Basilikon Doron outstrip it. The king's follow-up meditation of 1589, Ane Meditatioun upon the xxvi, xxvii, xxviii, and xxix verses of the xv chapt. of the first buke of the Chronicles of the Kingis, did not enjoy the same visibility as its predecessor; however, it was no less militant and its vision no less wide-ranging. The triumph over the Armada compared with the defeat of the Philistines and the return of the Ark to Jerusalem. Even more, the eschatological context apparently made "our victorie ... far mair then that of Israell's." The king further insisted that success against Spain resulted from mobilizing the nation: "men of all estaitis wer present in this godlie wark." And this in turn offered a lesson: a ruler could only succeed through godly counsel and through a godly ministry "appointit to be spirituall rewlleris of his [God's] Kirk"; "This is to be markit 
weill of Princes and all thois of ony hie calling or degrie that mellis to do in Goddis cause."' At the same time, in James's reading, the account in Chronicles of Michal's disapproval of David's dancing served less as a validation of music and celebration in the face of puritanical repression than as a generalized warning against "hypocrisy" - against those within the community whose heart was not with the triumph. The realm and its king now emerged in the forefront of the reformed cause. As the minister Patrick Galloway proclaimed in the preface, James promoted an "anefauld [unalloyed, honest] coniunctioun ... with the haill reformed christiane Kirkes in the earth." Through him ("the glorie and honour of earthlie kinges") they would together "enter in that new Ierusalem as citizens thairof." John Malcolm's liminary verses to Ane Fruitfull Meditatioun spoke of James fulfilling biblical prophecy and claimed "that the high walls of Rome were destined to fall to the arms you wield." His prefatory poems to Ane Meditatioun upon ... Chronicles further underlined James's sacred mission, a mission validated by the king's piety and his writings. ${ }^{8}$

The two meditations sought to do still more than frame the apocalyptic conflict and locate James within it. They are both unionist tracts and by implication make strong claims about the English succession. Neither England nor Scotland is ever named." James only speaks of "this Ile." When in Ane Fruitfull Meditatioun the king stirringly urges the "defence of our liberties, natiue countrie, and lyfes," readers might well have wondered momentarily what country he had in mind. But, clearly, for James our "natiue countrie" is Britain. Similarly in Ane Meditatioun upon ... Chronicles, when he speaks of defending "our natiue soill and patrie," he visibly believes that Englishmen and Scots inhabited a common realm and were in some sense a single people. The coherence of Britain, its shared mission and common cause, becomes dramatically underscored when James asks, "Is thair not now ane sincere professioun of the treuth amangest ws in this Ile oppugnit by the natiounis about, haiteris of the holie word." The Spaniards like the Philistines have "cummed out of thair awin soilles" threatening the "destructioun and wrak of ws." ${ }^{10}$ Britain becomes defined against the invading Catholic powers. British "soil" is now demarcated against that of Iberia. In crisis Britain has emerged the prophetic "belouit citie" besieged by the forces of Antichrist at the end of days. The use of the French "patrie" is suggestive, for the neologism "patriot" enters the Anglophone civic lexicon during just these years from France and Flanders. ${ }^{11}$ Although the king was firmly legitimiste and consistently rejected George Buchanan's political 
theories, he could nevertheless adopt a civic vocabulary which at this moment seemed perfectly compatible with reformed kingship. In 1593 James assured the English special envoy Thomas Burgh that he would choose "faithfull patriots and sincere professors of the reformed religioun to be his counsellors." ${ }^{12}$ Facing the second Armada crisis in 1596, he famously enjoined the public good and civic responsibility through a Tacitus-inflected declaration:

Lett us abhorre the beastlie Indians, whose unworthie particulars made the way patent to their miserable subjectioun and slaverie under the Spaniards; and let us preasse to resemble the worthie ancient Romans, who not onlie preferred their common weale to their owne particulars, but even to their owne proper lives. ${ }^{13}$

Civisme was essential. Bishops were not. At this juncture, we need to remember, King James had no a priori commitment to episcopacy and could comfortably imagine its total replacement. ${ }^{14}$ Reformed Scotland therefore carried political as well as theological and ecclesiological implications. All of them appeared to promise radical transformation. For however much James rejected autonomous clerical power or however fraught his alliance with the Presbyterian movement might prove, and tensions frequently verged on the explosive, the king and his new allies nevertheless found much in common. They publicly shared a similar theology, if not ecclesiology, an overlapping apocalyptic vision, and, crucially, a passionate British agenda.

Scottish state poetry, largely authored by John Malcolm's friend and St. Andrews colleague Andrew Melville, reinforced and elaborated upon the king's British project. Melville's celebration of Queen Anna's coronation in 1590, the $\Sigma \tau \varepsilon \varphi \alpha v ı \sigma \kappa l o v$, ad Scotiae Regem, Habitvm in Coronatione Reginae, spoke of "this great turning point of things" (hoc cardine rerum). With the dynasty now secure, the king could realize his destiny "to confront the hells and walls of Rome" which "shudder at the prospect of [British] power, their fatal arms faltering in the foreknowledge of defeat." Melville echoed Malcolm here, but went on in this extraordinary poem to echo and then develop many themes that had been announced by the king himself. James, the offspring of Fergus and of so many British kings, would prove "the promised champion of the northern sky." 15 Still, the prospect of grand eschatological and British vistas did not preclude a civic society. "Whether chosen by the people at large, whether succeeding to a 
hereditary throne"-Melville did not specify-the crown should lead through persuasion rather than coercion. "How much more desirable and blessed is it in a kingdom not to be compelled." ${ }^{16}$ Civic engagement drove the commonwealth. The conclusions could only prove activist. As the epigraph motto had it, "Be Wise-Be Bold-Begin."

Melville's poem for the birth of Prince Henry in 1594, Principis ScotoBritannorum natalia, adopted a more emphatically British voice. It envisioned Henry ruling a united "Scoto-Britannic commonwealth" and leading "ScotoBritannic champions" as part of a great Protestant confederation against the Spanish Empire and its papal ally. Both of these demonic enemies, Melville declared, would meet with destruction as Henry, "dear to heaven and dear to his fellow citizens, under God, / ... rejoices to have buried the insolent spirit of empire in its tomb. ${ }^{17}$ Like the $\Sigma \tau \varepsilon \varphi \alpha v ı \sigma \kappa ı o v$, the Natalia was a formal statement of government aspirations and an exercise in self-figuring, if not exactly policy: the first had been written at the request of the king and probably the second as well. ${ }^{18}$ Melville's colleague William Welwood had just secured the Natalia's republication at The Hague and thus its appearance on a European stage, when a diplomatic flap occurred. Robert Bowes, the English ambassador, was outraged that the argument of the poem was founded on a post-Elizabethan world, and thus the triumph of righteousness was predicated on the queen's demise. ${ }^{19}$ The succession question was not so much addressed as assumed.

Ambassador Bowes would have become still more indignant if he had been aware of the Gathelus, a national epic that Melville was composing during these years. In part a rejoinder to the first three books of Edmund Spenser's Faerie Queene-drawing on Scoto-Irish origin myth in the face of its AngloWelsh competitor-Melville's poem envisions two "streams" growing from Gathelus, the eponymous founder of the Gaels. One leads to the Iberian Celts and climaxes in the contemporaneous, rapacious Spanish Empire-its founder a Gaelic version of Ishmael. The other leads to the British Isles and climaxes in the emerging, civic British order-its progenitor of course the Gaelic equivalent of Isaac. Both now confront one another in the culmination of human history. ${ }^{20}$ If the Natalia sidelined Elizabeth, the Gathelus threatened to sideline England altogether-or at least subsume the southern realm within a larger British structure whose sources and energy derived from the north.

Ironically, Spenser's and Melville's reforming objectives largely overlapped, and their rival medieval mythologies, originally intended to counteract 
one another, now ran in the same direction. Further, both poets were participating in a pan-British reform movement that saw the triumph of sincere religion as bringing with it the triumph of the Muses. Spenser made this association in reference to Francis Walsingham, and so too did Melville's close associate David Hume of Godscroft. ${ }^{21}$ Spiritual reform promised to bring a cultural flowering, and thus "further reformation" carried with it (quite self-consciously) theological, ecclesiological, political, and still broader cultural implications. Though doubtless unintended by Spenser, Melville, or Hume, the culturalliterary manifestations of reform reached into what we would today call popular culture. The ferocious and wonderfully vulgar literary conflict regarding the Adamson-Arran regime-rooted in early sixteenth-century Scottish "flyting," and whose central 1580s figure was the Scottish poet and playwright Robert Sempill-anticipates if it does not inform the English Martin Marprelate/antiMartinist confrontation at the end of the decade. ${ }^{22}$ Radical Scotland signaled a profound reconstruction of society, framed within nothing less than world transformation and the fulfillment of human destiny.

We would go seriously wrong to see James's commitment to reform through the greying lenses of late twentieth-century cynicism. Yet we do need to recognize that, in the years immediately after 1585, alignment with further reformation may well have offered the most plausible strategy to the southern crown. The reform movement, not the bishops (seen simply as royal ciphers), could arguably comprise the most dynamic element within English society. The advice to James recorded by Hume of Godscroft made a great deal of sense:

Bishops there stand by the state, not the state by them: men of meane birth, no great riches, lesse following, attendance, or friendship, easie to be framed in whatever course [the king] pleaseth, their life-time being reserved or without condition. Those that seek Reformation are the strength of that countrey, and certainly the wisest in it, of greatest power by the peoples favour, and credit in Parliament, and everywhere ... Gaine these, gaine that countrey. ${ }^{23}$

As Patrick Collinson recounted long ago, in 1584 the reform movement mounted its most determined challenge to the Elizabethan order, turned back only by the resolution of Whitgift and the queen herself. ${ }^{24}$ Crucially, it had been a pan-British struggle, and quite self-consciously so, destabilizing Edinburgh 
no less than London. Here lay a common tradition that had reached back decades. Such an upheaval might happen again-and triumph. If the key reforming leaders (most prominently, Angus, Leicester, Walsingham, Mildmay, and Sidney) had survived through the 1590s rather than the indestructible Elizabeth, the prospect of further reformation might well have carried James to London. Counter-factual history can never tell us what would have happened, but it can give us a sense of the options available. In the world before Anglicanism, a number of alternate futures were on offer, the most visible and contested being the reforming movement. As late as 1605 Hume of Godscroft, who knew England well, believed that if the people of the two realms had the choice they would choose reform. No "edicts" were required. James need only give his "nod." ${ }^{25}$ Seen from Edinburgh, radicalism not only proved spiritually compelling, it also best served the interests of the king, the realm, and the reformed cause generally. Further, it increasingly appeared to lie at the heart of the prophetic future and human destiny.

It is out of this context that we need to understand the frequently-noted policies and declarations emanating in these years from the Scottish government. James himself famously declared in 1590 before the General Assembly that the Scottish Church was the best reformed in Christendom, even better than Geneva, and, implicitly but unmistakably, provided the model for the Protestant world. By contrast, the Church of England was severely corrupted, its liturgy "an evill said masse in English, wanting nothing but the liftings." Accordingly, both the king and the church made representations on behalf of persecuted English reformers and "puritans" such as John Udall and Thomas Cartwright. Still more provocative, Robert Waldegrave, a printer of the delightful if inflammatory Marprelate tracts and a man on the run from the English authorities, turned up in Edinburgh where he published works for the church and subsequently became the crown's (and thus Melville's) official printer. Nor was Waldegrave the only Marprelate refugee now active in Scotland. ${ }^{26}$

At home James repeatedly committed himself to implementing the reform program, and contemporaries found every reason to believe what he said. Close relations between the decisively influential chancellor, John Maitland of Thirlestane, and Robert Bruce, Andrew Melville, and Hume of Godscroft made these reforming leaders far more court figures than either they or the king would later prefer to remember. In 1592 the Presbyterian church structure (though not clerical power) became law in Scotland. Two years before in 
"a short harrangue" the king explained that his earlier failure to implement thorough-going reform (i.e., during the Adamson-Arran regime) had resulted "partlie through the injurie of the tyme and partlie through his youth." Here was a "harrangue" he surely made more than once, and at the time something he probably meant. Even so, Scotland was also a country of the "General Band" to uphold the law and protect the realm, and of the great 1581 anti-papal oath that increasingly came to be called a "covenant"-all of which enjoined public responsibility, civic engagement, and direct action. ${ }^{27}$ Viewed from across the frontier, Scotland emerged a beacon to reformers, relevant as never before. Even in 1603 enormous hopes were raised by the king from Scotland. If in the event he proved a massive disappointment, such expectations did not seem misplaced a decade earlier. And everyone knew it. English conservatives and the increasingly assertive episcopal order had good reason to be worried-if not downright terrified.

\section{Reactionary England}

"See what hath come by it [Presbyterianism] in Scotland:

Forsee what will become of it here."

-Thomas Nashe, $1589^{28}$

In 1588-89 southern opponents of reform confronted an ominous future. Before them lay a determined, well-organized reform movement at home closely joined to a Presbyterian state just to the north. As if that were not enough, at its head stood a monarch who not only had a strong claim to the English throne but who had become identified with a reforming and, worse, specifically British agenda. As has long been recognized, these potentially dire circumstances thoroughly alarmed the English bishops and their court allies. ${ }^{29}$ However, the scope of their response, whose outcome appears assured only in retrospect, has no more than just recently attracted attention.

Conservatives met the looming danger with a ferocious counteroffensive. Spearheaded by Richard Bancroft, it directly rejected every element within the British program for further reformation. In his "A Sermon at Paules Crosse" (1589) and subsequently in his Dangerous Positions and Proceedings and A Survey of the Pretended Holy Discipline (both 1593), Bancroft sought to 
discredit the reformers as subversive to royal authority, foreign to English tradition, and corrosive to English spirituality. Specifically, he denounced "Scottish Geneuating for Discipline," dismissed apocalyptic expectations as Jewish posturing, and warned threateningly about revolution, John Knox, and especially George Buchanan. Let not the northerners "cast some of their contentious and disloyal seedes into England." ${ }^{30}$ Scottish political theology was un-English. More than that, Bancroft implied, it comprised nothing less than a threat to civilization itself.

Unlike earlier inter-Protestant disputation in England, the sermon did not intend to convince dissidents. As Mary Morrissey points out, Bancroft adopted the style of anti-Catholic preaching which seeks to warn waverers about hidden dangers and disguised subversion. ${ }^{31}$ Manifestly, Bancroft neither asked nor expected any reformer or any Scot to think it possible that he might be mistaken. His enemies have now become identified with foreigners, and it is likely the Scottish peril rather more than the Marprelate uproar prompted him to take up the new hard-edged rhetorical structure.

Scottish response came quickly, and the lead-off argument against Bancroft's calumnies was his subversion of the "most joyfull and fruictfull amitie" into which "it hath pleased God to joyne these two Realmes." Again and again Scottish ministers spoke of "the blessed amitie" and "the happie amitie." Bancroft was no "favourer of the amitie between the two lands, but a sworne ennimie." 32 What could possibly be more dangerous in the face of the war with Spain and in the wake of the recent deliverance than division between England and Scotland? The Scots countered English episcopal Scotophobia with the British common cause. The ministers palpably meant more than the 1586 Treaty of Berwick. At least since John Knox and even since the 1540s, "amity" had served as a buzz-word for Anglo-Scottish union. Bancroft, the Scots insisted, worked to subvert the Anglo-Scottish Reformation project and thereby Britain. The dispute between the Scottish clergy and Richard Bancroft involved far more than church discipline. The issue was the post-Elizabethan era.

However, there was one and only one Scot whom Bancroft did hope to persuade. Bancroft claimed that the Scots only got it right in 1584 when the "Black Acts" established an episcopal church under an imperial, Constantinian crown. The "Declaration" that enjoined the new order, Bancroft asserted, expressed King James's true feelings-notwithstanding the overthrow of Arran-Adamson in late 1585 . His remarks about the Scottish king may have been "profoundly 
wrong," but we should not see them as a misapprehension or wishful thinking, and still less as a tactical blunder. ${ }^{33}$ True enough, the sermon did precipitate an international incident, for Bancroft had effectively impugned the king's intentions and character. Burghley hauled him in, and the Lord Treasurer's reproof with demand for an explanation probably proved harsher than Bancroft expected. Yet Bancroft's strategy is clear and he never deviated from it. On the one hand, he worked to detach the king from the Scottish church and the reform program..$^{34}$ On the other, he separated James's possible succession from any projected British union-though in fact the sermon can only have darkened the king's succession prospects.

Bancroft's "Submission" to Burghley hardly constituted a retraction. The Scottish "sectaryes" encouraged "the malcontents of this state" and threatened to "hazard" all Christian kingdoms. Knox and Buchanan bore out his claims. Bancroft barely hedged about James's intentions: the king's extraordinary clemency to his outrageous subjects might be extended to himself- "my fault if his ma[jes]tie shall so account it." At three points Bancroft insisted that he had never intended to breach "the unitye of the two realms"- he was hardly "a madd man." Yet it is simply impossible to imagine how there could exist "unity" with a society organized on principles that overthrew rationality itself. ${ }^{35}$ "Unity" inherently mandated that James could not believe what he had in fact said.

The anti-Scottish drumbeat continued immediately thereafter in the popular literature that Bancroft sponsored to counter the Marprelate tracts, and forms part of an ongoing campaign that directly links the 1589 sermon with Bancroft's 1593 writings. Thomas Nashe's 1589 warning about the Scottish experience, cited above, echoes language in the sermon. ${ }^{36}$ Much the same language about Scotland also crops up elsewhere among the opening salvos of the anti-Martinist campaign. Leonard Wright similarly borrows from the sermon in his 1589 The Hunting of Antichrist, with a caueat to the contentious in order to alert Englishmen about the disastrous Scottish miscarriage. ${ }^{37}$ The earliest anti-Martinist writings came in the form of doggerel verse, and, perhaps predictably, one of them adopted an ersatz Scottish voice. The verses never pretend to offer a Scottish perspective or even mention Scotland, though they do name both England and Elizabeth. Their point is to associate reform with the foreign. In the process, the verses laid the groundwork for what would take shape as the commonplace Scottish caricature during the next decade. Accordingly, 
poems immediately following the one in painful faux Scots speak of "English lawes," "our England," "O England" which had long overcome "forraine force."38 Reform, one might think, was every bit as alien as the Armada.

Bancroft visibly disliked public stage-plays as much as did any other repressive cleric, and his hearty contempt for the lower orders arose naturally from his hierarchical commitments. "It falleth not within the compas of everie mans understanding to determine and judge in matters of religion." "Husbandmen, Dawbers, Smiths, Carpenters [!], Woosters, Fullers, and other men of such like occupations ... are content to learne of their masters." ${ }^{39}$ But he realized better than many of his opponents how popular performance could transform opinion. Marprelate had opened religious policy to the cut and thrust of everyday discourse, and Bancroft, as he later indicated, feared that the reformers might "steale away the hartes of her Majesties subiectes." ${ }^{40}$ The establishment's counter-blast, which now aimed at the new broader audiences, necessarily targeted the Scots.

Throughout the summer of 1589, Martin Marprelate, reform, and Scotland found themselves skewered in staged burlesques, ribald verses, and in tracts both scurrilous and sanctimonious. During the course of the 1590s such writings went on to create the stage puritan, the stage Ramist, the stage Scot, and, often closely associated with the Scottish caricature, the stage Jew. ${ }^{41}$ All of this anti-reformist writing - which at once lampooned and invented these figures-resulted in a reactionary, populist counter-culture that persisted for more than a century and in some ways still informs the modern world. Reform in a raunchy register had become a weapon. But, as Nashe quickly made clear, that weapon carried with it a recoil action. ${ }^{42}$ Buchanan's civic society could be turned on itself. Decades later, a former Scottish radical declared that Scots ministers at the time "read Buchanan's little book De jure more diligently than they read Calvin's Institutes." Bancroft obviously thought so. ${ }^{43}$ The survival of the English church and indeed of civilization itself required their defeat-even if that meant adopting a new populist voice.

Scots responded indignantly to the new literature, done in a "verie ignorant maner." "We, our discipline, and the whole ministre, are most ridiculouslie flooted ... in ther stage playes, pamphletis, and pasqwillis, imprinted day by day." The 1589 protest initiated what came to be an ongoing tradition of abuse and complaint, involving church leaders, the Edinburgh city council, and even Hume of Godscroft himself. ${ }^{44}$ If Marprelate resurfaced half a century later at the 
outset of the British Revolution with English radicals such as Richard Overton, so too did its reactionary analogue, with such anti-Scottish/anti-British writers as John Tatham and John Cleveland. In 1589 the Scots warned, perceptively, about the divisiveness of these writings in their homeland, and at the same time about their poisonous effect on relations between the two countries. "So can it not but muche coole our kindnes, which God forbid, to the great indangering of all." 45 The term "kindness," used here in the sense of the obligations of kinship, is telling, for it meant that the natural bonds between the two peoples were being weakened. The popular literature (anti-episcopal Marprelate of course goes unnoticed) threatened the British future-as was its purpose.

By the next year, anti-Scottish satire and invective had become commonplace. Nashe's An Almond for a Parrat (1590) linked Scottish spirituality with Celtic primitivism: "Your beleefe forsooth must be of that Scottishe kinde ... Good God, that a Welch harpe should inchant so many English harts to their confusion." The reform program, now tarred as both alien and barbarous, rendered English reformers even worse than those archetypal barbarians, the Scythians, who at least rejected foreign innovations. Nashe, completely at one with Bancroft, finds reform to be Scottish and, by being so, promoting barbarism, not the Muses. ${ }^{46}$

Still, much popular writing avoided blatant abuse, barely mentioning Scotland, yet nevertheless worked to discredit the northern realm and trouble the Stewart succession. One such is Nashe's hugely successful Pierce Penilesse His Svpplication to the Diuell (1592). It has been long recognized that Nashe draws on continental Catholic writings to identify the devil's workings with the English Privy Council and the repressive measures introduced in 1591. But more was at issue. The devilish actions of the Privy Council formed part of a broader assault on the true (Catholic) faith. Where is the devil at the present moment? "Hee is busie with ... the prince of the North." His purpose there is to "build vp his kingdome" or to subvert those who would discredit it. ${ }^{47}$ There could be only one such northern prince at this point on everyone's mind, and only one building up his kingdom in this way (on Nashe's telling, a demonic kingdom): James VI.

Nashe no doubt pursues a number of English political figures, but one in particular stands out. Pierce Penilesse unmistakably and at moments all but explicitly targets Robert Devereux, Second Earl of Essex. When Nashe says, "Al Italiano is his talk, \& his spade is as sharp as if he had been a Pioner before the 
walls of Roan," he obviously means Essex's role in the abortive 1591 siege of Rouen. When Nashe says, "he hath ... fought withe yong Guise hand to hand" or speaks of his concern for "leading armies into Fraunce," we plainly encounter Essex. ${ }^{48}$ Similarly, when Nashe describes his target as "one being ready to dispaire of himself, if he sees the Prince but giue his fellow a faire looke: or to die of griefe if he be put down in brauery neuer so little," he obviously refers to Essex's severe tensions with Charles Blount and Walter Ralegh. ${ }^{49}$ Nashe singles out Essex in this way, partly because the earl promoted the godly at homeand urged an aggressive policy toward the Spanish Empire-and most notably because since 1589 he had linked up with James VI to secure his succession. Burghley's anti-Catholic measures may have been inspired by the devil-that is, measures sought, promoted, and celebrated by the north. But Essex actually meant to bring the devil south.

No less revealing is Pierce Penilesse's prominent parable. In it Nashe derisively notes "the imputed goodnes of the Soyle [and] of carefull diligence of the Gardners [the clergy] aboue ours [in England], as for example, Scotland, Denmarke, and some more pure partes of the seauenteene Prouinces." The link between Scotland and Denmark surely refers to James's new bride, and the malignant northern world that has now emerged. This is a radical world, subversive and terrible, that would "purge" people of "their olde Traditions and Customes. ${ }^{50}$ It is surely no accident that Nashe goes on at extraordinary length about Danish barbarism and how the Danes "naturally hate learning." Linking them with the Islamic world and the false, indeed demonic faith, Nashe adds, "Not Barbary it selfe is half so barbarous as they." Nashe's virulence is pointless outside the Scottish context.

Why in the world did Nashe make a "supplication to the diuell"? No other contemporary controversial or polemical work appears at all like it. This is odder still because Nashe spends page after page in his final section arguing with vast classical erudition - and no irony or humour whatsoever-that demons do exist in nature. These creatures do not merely tempt our minds but confront our bodies. No laughing matter, for demons are real and they are everywhere, as any learned man could tell you. ${ }^{52}$ Bitter irony finds itself supplanted by fearsome reality. Nashe's firm belief in the reality of demons and witchcraft appears in several of his other writings. ${ }^{53}$ It fits well with his religious conservatism.

But where are demons active right now? The answer could only be Edinburgh and the witch crisis of 1590-91-a crisis directly involving James 
and his new bride. Nashe need not have read the account in News from Scotland (1591), though it is hard to imagine he was unfamiliar with it (he constantly refers to "news"). ${ }^{54}$ The dramatic events in Scotland had inevitably attracted considerable attention. Nashe may well have known about the Danish preoccupation with witchcraft as well; a truly dangerous position lay in the north, and the coming of the Scots could only mean catastrophe.

Nashe's rollicking nastiness should not mislead us. The primitive invited Satan not through credulity but through the vulnerability created by false faith, misconceived authority, and lack of civilization. In the same year Nashe composed his Svmmers Last Will and Testament. The play rehearses a number of the themes in Pierce Penilesse. King Summer laments Winter's attack on art and learning, and, Marie Axton informs us, speaks to the looming Scottish future. Contempt for the old aristocracy, tradition, and art now extended to "mirth"to the local celebrations of hierarchy and customary authority. "It is the honor of Nobility / To keep high dayes and solemne festiuals." ${ }^{55}$ Wintry Scottish night threatened to descend and darken everything of value in England. It was only appropriate that Nashe lodged this year at Croyden, the summer home of the archbishop of Canterbury, and that Svmmers Last Will and Testament was performed there that autumn. ${ }^{56}$ Nashe served as an integral part within a coherent offensive, and accordingly his writings flow seamlessly into those authored by Bancroft in the following year.

Bancroft's brutal 1593 critiques of the Scottish church and his continued efforts to detach James from it are well known. ${ }^{57}$ Less prominent is his sly association of Buchanan's political thought with Irish primitivism. Bancroft discounts Buchanan's virtuous citizen who rejects "pomp" as an impoverished figure who lives "after the Irish fashion." ${ }^{8}$ Yet Bancroft's determination to prevent a "Scottish" settlement in England pales before that of his colleague Richard Hooker. In that year Hooker, with help from Edwin Sandys, inaugurated a new spirituality through his Lawes of Ecclesiastical Politie (first four books, 1593), a spirituality that stressed the transforming effects of the sacraments, clerical authority, and the centrality of Christ's sacrifice. If Bancroft qualified the Protestant eschatology and limited appeals to it, Hooker rejected it altogether. Apparently Hooker concluded that 1584 was now lost beyond recovery, for he judged it "altogether too late" to change things in the northern realm. ${ }^{59}$ The point was to secure the English church on a proper sacerdotal basis. Scotland, benighted and irrelevant, could go its own way. 
Although Hooker climaxes the English anti-reform movement in highly original ways, his thinking was far from culturally isolated. As Glenn Burgess pointed out long ago, Hooker's work accompanied an "intensification" within English legal thought that emphasized the autonomy of the common law, drew strength from antiquarians, and was motivated "by the need to defend the Elizabethan settlement." ${ }^{60}$ At the same time, English legal thinking detached itself from the traditional Anglo-Welsh mythology and found its sources immemorially within Germanic antiquity. As with Hooker's vision of the church, English civil institutions acquired an internal coherence severely dissociated from the north. The growing appeal to "fundamental law" spoke to a world of private right and institutional privilege rather than to civic action, and was founded on juridical continuity rather than political decision-taking. Deeply conservative, the new sensibility inherently insulated England from the foreign. ${ }^{61}$ It is probably no accident that Hooker's sponsor and former student Edwin Sandys played a key, possibly decisive role in the parliamentary defeat of Anglo-Scottish union after 1603.

The Episcopal counter-offensive proved altogether effective in many ways. It secured English institutions against both foreign and domestic incursion, affirming an unbroken tradition that precluded change. It validated hierarchy, tradition, and authority, while severely constricting vocabularies of reform and innovation. ${ }^{62}$ In the end it did not prevent James's succession, but it did foreclose the Jacobean British future.

\section{Notes}

1. The paraphrase would only see print in the 1616 edition of the king's collected works. James [Montagu], bishop of Winton, ed., Workes of ... Iames ... (London, 1616), pp. 7-12. Montagu notes that the king wrote his paraphrase while still a teenager ("To the Reader"). A warning against "divers" who "in our aage" read the Revelation according to "their particular and private passions" prefaces the printed version which was surely not a part of the original. The warning most likely intended Thomas Brightman's Revelation of the Revelation (first published in 1609). See A. H. Williamson, Scottish National Consciousness in the Age of James VI (Edinburgh: John Donald, 1979); A. H. Williamson, "Scotland, Antichrist, and the Invention of Great Britain," in New Perspectives on the Politics and Culture of 
Early Modern Scotland, ed. John Dwyer, Roger A. Mason, and Alexander Murdoch (Edinburgh: John Donald, 1982), pp. 34-58; A. J. Stilma, "King James VI and I as a Religious Writer," in Literature and the Scottish Reformation, ed. Crawford Gribben and David George Mullen (Farnham: Ashgate, 2009), pp. 127-41, p. 131; A. J. Stilma, “'As Warriouris in Ane Camp': The Image of King James VI as a Protestant Crusader," in Apparelling the Truth: Literature and Literary Culture in the Reign of James VI, ed. Kevin J. McGinley and Nicola Royan (Cambridge: Cambridge Scholars, 2010), pp. 241-51. James's adoption of a determined Protestant outlook and persona in the later 1580s has often been observed, most recently by Jane Dawson in an untitled review, The Journal of Ecclesiastical History 62 (2011), pp. 165-66, p. 166.

2. Ane Fruitfull Meditatioun (Edinburgh, 1588), sig. B4r.

3. Ane Fruitfull Meditatioun, sigs. B2v, B3r.

4. Ane Fruitfull Meditatioun, sigs. B3v, B4r.

5. Ane Meditatioun upon ... the Chronicles (Edinburgh, 1589), sig. B3v. Phrasing from Chronicles appeared in Revelation, and therefore linked the two. Scripture, James explained, could only be explicated properly through scripture. Arbitrary constructions were thereby precluded.

6. Ane Meditatioun upon ... the Chronicles, sig. B1r.

7. Ane Meditatioun upon ... the Chronicles, sig. A2r (“To the Christiane Reider"); see Williamson, Scottish National Consciousness, pp. 39-43.

8. Ane Fruitfull Meditatioun, sig. A2v: Fati dici cecinere patres, quod moenia Romae / Alta forent armis, Rex, ruitura tuis. Malcolm stresses that James confronts "the monster of the many heads" through the might of the "Holy Spirit," while "the dire thing, the enormous Beast" bears "carnal arms." Another poem in Ane Fruitfull Meditatioun plays skilfully on James's "name"/"renown.” Regarding Malcolm, an associate of Andrew Melville, see S. J. Reid, Humanism and Calvinism: Andrew Melville and the Universities of Scotland, 1560-1626 (Aldershot: Ashgate, 2011), 139ff. A. J. Stilma suggests that James may have been assisted by a cleric, possibly Patrick Galloway, but she is careful not to claim that the text is other than the king's; see Stilma, "King James VI and I as a Religious Writer," pp. 135-37; see also Stilma, A King Translated: The Writings of James VI \& I and Their Interpretation in the Low Countries, 1593-1603 (Farnham, Surrey: Ashgate, 2012).

9. Nor for that matter is Elizabeth. Only in the frontispieces does James appear as "King of Scottis." Unlike James, Malcolm does refer to Scotland, in his liminary epigram to the second meditation: "O happy Scots that we are under our King David 
/ Endowed as he is with the knowledge of the true God. / Therefore, Scotland, sing God's praises, / No country will ever give forth such a king or [one] so great as this" "“O nos foelices nostro sub Dauide Scotos, / Imbuto veri cognitione Dei. / Ergo Deo laudes semper cane, Scotia, Regem / Tantum et enim, \& talem patria nulla dabit"). Ane Meditatioun upon ... the Chronicles, sig. A2v. For just this reason, Malcolm's poem, unlike his verses prefacing the first meditation, would be dropped from the 1603 English "translations" of these works and from the 1616 collection. It did not fit the purpose of the meditations.

10. Ane Fruitfull Meditatioun, sigs., B2v, B4r; Ane Meditatioun upon ... the Chronicles, sig. B3v.

11. See A. H. Williamson, "The Rise and Decline of the British 'Patriot': Civic Britain, c. 1545-1605," International Review of Scottish Studies 36 (2011), pp. 7-32. The 1603 London edition and "translation" Ane Meditatioun upon ... the Chronicles (along with the 1616 edition of James's works) renders "patrie" as "country." $A$ Meditation, sig. B7r.

12. So it was recorded by David Calderwood, History of the Kirk of Scotland, ed. T. Thomson, 8 vols. (Edinburgh: Wodrow Society, 1842-49), vol. 5, p. 239. William Camden's Annals renders James's remarks as: “... that he would take into his councell men of sound judgement, and sincere religion, and love to their countrey." Annals, or the Historie of the Most Renowned ... Elizabeth, trans. R. N. (London, 1635), p. 418. Our thanks to Malcolm Smuts for drawing the comment in Calderwood to our attention.

13. Calderwood, vol. 5, p. 391.

14. A. R. MacDonald, The Jacobean Kirk, 1567-1625: Sovereignty, Polity and Liturgy (Aldershot: Ashgate, 1998), pp. 36-37, 50. Nor was the Presbyterian commitment to the "two jurisdictions" as robust and thorough-going as it later became in the wake of confrontation and set-back.

15. $\Sigma \tau \varepsilon \varphi \alpha v ı \sigma \kappa ı$ (Edinburgh, 1590), sigs. A2r, A2v. ... quem septem arceis et moenia Romae / Iam dirum hostem horrent, fataliaque arma tremiscunt, / ... poli certissima proles. Melville refers to Paul Grebner's widely-known prophecy about a lion of the north emerging at the end of days to reform the world. See P. J. McGinnis and A. H. Williamson, eds. and trans., The British Union: A Critical Edition and Translation of David Hume of Godscroft's De Unione Insulae Britannicae (Aldershot: Ashgate, 2002), pp. 41-42, 167-71; Keith Thomas, Religion and the

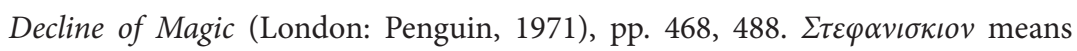


"little crown," thereby celebrating the Queen's coronation. The neologism is apparently Melville's own. Our thanks to Mark Riley for helping us run down this term.

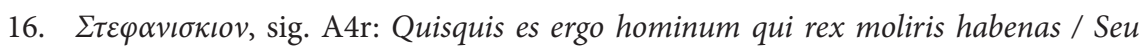
lectus magno e populo. Seu natus auito / In folio ... . Melville repeatedly insists that kings exist for citizens, not citizens for kings. "Who in a word believes that his citizens are given over to him rather than he to them? O kings! Isn't it true that a commonwealth is entrusted to your bosom / By the gift of men and by divine favor ... ?" (sig. A4v: ... qui denique secum / Non putat ipse datum se ciuibus: at sibi cives. / Nonne est dono hominum \& diuino munare, Reges / In vestrum collata sinum Respublica ... ). Yet Melville was pointedly conscious of the problems of ruling and of securing agreement.

17. P. J. McGinnis and A. H. Williamson, eds. and trans., George Buchanan: The Political Poetry (Edinburgh: Scottish History Society, 2000), pp. 276-81.

18. Melville prefaced the $\Sigma \tau \varepsilon \varphi \alpha v ı \sigma \kappa ı v$ with a charming poem to the king. In it he comments, "What thou didst command yesterday, I finished today" (Ius isti quod here, egi hodie). Melville's nephew and confidant James Melville commented in his diary that "Mr Andro haid nocht bein warnit to this Coronation in anie convenient tyme, and haid na thing preparit bot sic as cam in his meditation a night or twa." The poem was published at the king's command, and, the younger Melville tells us, James "gaiff him grait thankes, saying, he haid sa honored him and his countrey that day, that he could never requyt him." Melville goes on to add that the poem earned the praise of Joseph Scaliger and Justus Lipsius. See Melville, The Autobiography and Diary of Mr. James Melville, ed. R. Pitcairn (Edinburgh: Wodrow Society, 1842), p. 279.

19. Calendar of State Paper Relating to Scotland, 1593-95, vol. 11 (Edinburgh, 1936), ed. A. I. Cameron, pp. 430-31; Original Letters of Mr John Colville ... (Edinburgh: [John Hughes], 1858), p. 120; Principis Scot-Britannorum natalia (Den Haag: Aelbrecht Hendricksz, 1594). See Andrew Pettegree and Malcolm Walsby, eds., Netherlandish Books: Books Published in the Low Countries and Dutch Books Printed Abroad before 1601, 2 vols. (Leiden: Brill, 2011), vol. 2, p. 916 (\#21047). The diplomatic debacle has been variously noted, but no commentator has discussed what Melville actually said: e.g., N. Tyacke, "Puritan Politicians and King James VI and I, 1587-1604," in Politics, Religion, and Popularity in Early Stuart Britain, ed. Thomas Cogswell, Richard Cust, and Peter Lake (Cambridge: Cambridge University Press, 2002), pp. 21-44, pp. 26, 27. Tyacke's piece is all the more surprising because he reproduces the Natalia frontispiece. It is probably also misleading 
for Tyacke to claim that James had given his "permission" to publish Melville's verses. As in the case of the $\Sigma \tau \varepsilon \varphi \alpha v \iota \sigma \kappa \iota$ v, he had most likely commanded it-even if the king ran for cover once the complaint surfaced.

20. McGinnis and Williamson, Buchanan, pp. 284-97. The poem never seems to have been completed, and only a brief fragment saw print in 1602. See P. J. McGinnis and A. H. Williamson, "Britain, Race, and the Iberian World Empire," in The Stuart Kingdoms in the Seventeenth Century, ed. A. I. Macinnes and J. Ohlmeyer (Dublin: Four Courts, 2002), pp. 70-93, pp. 83-93; McGinnis and Williamson, The British Union, pp. 9-23; A. H. Williamson, "Empire and Anti-Empire: Andrew Melville and British Political Theology, 1589-1605," forthcoming.

21. David Hume, Poemata omnia (Paris, 1639), pp. 72-73 (Third Part, "Lusus, poetici," paginated separately); A. H. Williamson, "Radical Britain: David Hume of Godscroft and the Challenge of the Jacobean British Vision," in The Accession of James I: Historical and Cultural Consequences, ed. Glenn Burgess, Rowland Wymer, and Jason Lawrence (Houndmills: Palgrave, 2006), pp. 48-68, pp. 48-49. See Spenser, “The Rvines of Time," ll. 435-41; dedicatory sonnet to Walsingham, prefacing the Faerie Queene.

22. See Williamson, Scottish National Consciousness, pp. 58, 167, n. 42, 183-84, n. 48; J. Cranstoun, ed., Satirical Poems of the Time of the Reformation, 2 vols. (London: Blackwood, 1891-93); Priscilla J. Bawcutt, “Sempill, Robert (d. 1595?)," Oxford Dictionary of National Biography, Oxford University Press, 2004; online edn, Jan 2008 [http://www.oxforddnb.com/view/article/25075, accessed 8 January 2012] (henceforth $O D N B$ ). See J. Wormald, "Ecclesiastical Vitriol: The Kirk, the Puritans and the Future King of England," in The Reign of Elizabeth I: Court and Culture in the Last Decade, ed. John Guy (Cambridge: Cambridge University Press, 1995), pp. 171-91, p. 188.

23. David Hume, History of the House of Douglas (London, 1644-48), part 2, p. 427. See Williamson, Scottish National Consciousness, p. 135. The advice is almost certainly Hume's own.

24. Patrick Collinson, The Elizabethan Puritan Movement (London: Jonathan Cape, 1967), part 5. See also Gordon Donaldson, "Scottish Presbyterian Exiles in England, 1584-8," in Scottish Church History Society 14 (1954), pp. 67-80, reprinted in Donaldson, Scottish Church History (Edinburgh: Scottish Academic Press, 1985), pp. 178-90; Williamson, Scottish National Consciousness, pp. 66-68, 75, and passim. 
25. McGinnis and Williamson, British Union, pp. 242-47. Both English and Scottish Presbyterians firmly believed that most people wanted reform and also that in any fair debate they would triumph resoundingly. Cartwright and Melville shared these assumptions. Such belief provides the basis for Marprelate.

26. Calderwood, vol. 5, pp. 90, 106, 131-32; G. P. V. Akrigg, ed., Letters of James VI and I (Berkeley: University of California Press, 1984), pp. 110-12. Waldegrave was serving as printer to the Scottish church by March 1590, and despite some difficulties with James became the royal printer on 9 October 1590. Waldegrave is reported to have been in La Rochelle in 1589 and may possibly have had some connection with the French edition of James's Ane Fruitfull Meditatioun, "suyuant la copie qui en est imprimee en Escossois à Edenburgh." That alone would have earned James's favour. Long connected with Scotland, Waldegrave had printed Knox's confession of faith in 1581, as well as books banned by the English government but welcomed north of the border. See A. J. Mann, "Waldegrave, Robert (c.1554-1603/4)," Oxford Dictionary of National Biography, Oxford University Press, 2004; online edn, Jan 2008 [http://www.oxforddnb.com/view/article/28441, accessed 31 October 2011]. Waldegrave's "fugitive" status became a commonplace in the popular literature of 1589. See Thomas Nashe, Martins Months Minde (London, 1589), sigs. G2v, H3v. Another hunted man and far more prominent target of Elizabethan vengeance, John Penry, continued to write, publish, and defend the Scottish church under the protection of the northern realm.

27. Calderwood, vol. 5, pp. 48-52, 98. See Williamson, Scottish National Consciousness, pp. 66-69, and chapter 3 generally. The role of Jean Fleming, Lady Maitland, in Scottish politics during these years has gone largely unnoticed. Fleming helped shape her husband's policies, was committed to the Presbyterian cause, and had a particularly close connection to the minister Robert Bruce. It is no accident that Hume memorialized her in his poetry. See P. J. McGinnis and A. H. Williamson, "Politics, Prophecy, and Poetry: The Melvillian Moment, 1589-96, and its Aftermath," Scottish Historical Review 89 (2010), pp. 1-18, p. 12.

28. [Thomas Nashe], Martins Months Minde (London, 1589), sigs., F3v-F4r. Nashe refers specifically to what he saw as Presbyterian spoliation of the church-for him the real motivation behind reform.

29. Most notably by Wormald, pp. 171, 174, 178.

30. Richard Bancroft, "A Sermon at Paules Crosse" (1589), pp. 6, 8, 10-11, 19, 38, 57, 72; Dangerous Positions and Proceedings (1593), pp. 30-34, 71, 128, and passim. 
Bancroft's disclaimer that he did not intend to "be in any waies offensive to the meanest of that nation" (Dangerous Positions, p. 34) fooled no one.

31. Mary Morrissey, Politics and the Paul's Cross Sermons, 1558-1642 (Oxford: Oxford University Press, 2011), pp. 192, 193, 210.

32. "To the Most Mightie Princes ... Elizabeth," and John Davidson, D. Bancrofts Rashnes in Rayling against the Chvrch of Scotland (Edinburgh, 1590), both reprinted in D. Laing, ed., Miscellany of the Wodrow Society (Edinburgh: Wodrow Society, 1844), pp. 490, 495, 506.

33. Bancroft, “Sermon," pp. 73, 75; Wormald, p. 187.

34. A matter about which the Scots clergy were acutely sensitive: "we and our ministrie by that means [were] being made odious ... in the eies of our native Prince and State" in Miscellany of the Wodrow Society, p. 490. Bancroft's effort to detach James from Scottish radicalism was urgent, even desperate, for there existed no other candidate obviously attractive to England's Protestant conservatives. King James at one juncture believed that Robert Cecil and conservatives on the English Council "favoris the house of Hartford," and Cecil's friendly relations with the archdukes in the Spanish Netherlands prompted wild rumours that they endorsed the Infanta's succession. Yet the Scotttish king enjoyed a unique advantage, as everyone knew. See A. Gajda, The Earl of Essex and Late Elizabethan Political Culture (Oxford: Oxford University Press, 2012), pp. 186-87, and n. 229.

35. Bancroft's "Submission" is reprinted in Owen Chadwick, "Richard Bancroft's Submission," Journal of Ecclesiastical History 3 (1952), pp. 58-71, pp. 61-69.

36. Bancroft asserted that "the spoile of the Bishops livings, [and] of the cathedrall churches" was what motivated the so-called reformers and was the chief cause of schism ("Sermon," pp. 23-24). Nashe echoed, "you shoot at church liuings, you hope to haue the spoyle" (Martins Months Minde, sig. F3v). Jennifer Andersen has argued persuasively that Nashe echoes Bancroft and Whitgift's theological positions in his The Vnfortunate Traueller (London, 1594), "Anti-Puritanism, Anti-Popery, and Gallows Rhetoric in Thomas Nashe's The Unfortunate Traveller," Sixteenth Century Journal 25 (2004), pp. 43-63.

37. Leonard Wright, The Hunting of Antichrist (London, 1589), p. 27. “... the example of your fellow reformers in Scotland (who by altering the ancient state and propertie of ecclesiasticall liuings ... [and brought poverty as a result]) may bee a warning sufficient to teach you."

38. [John Lyly and Thomas Nashe], Mar-Martine (London, 1589), sigs. A3r-A4r ("No pitie twere to cut the combe of sik a chauntecleere" and untitled verses following). 
The upstart reformers/Scots are impoverished men on the make ("That they whaes fathers were bot kernis, knauis, clownis, \& booris, / Moght perke as paddocks, ligg in soft, \& swarth their paramoris"). They seek power and inhabit a Jewish world ("Els clarkis will soon all be Sir Johns, the preistis craft will empaire, / And Dickin, Jackin, Tom \& Hob mon sit in Rabbies chaire"). They are the enemies of literature and learning ("Els litrature mon spredde her wings, \& piercing welkin bright: / To heaven from whence she did first wend, retire and take her flight"). Still other verses noted: "Those seedes take roote which forraign seedes men sow." There could be little doubt as to where the "foreign seedsmen" originated. Marre Mar-Martin: or Marre-Martins medling, in a manner misliked (London, 1589?), sig. A3r, reprinted as an appendix to Leonard Wright, A Friendly Admonition to Martine Marprelate and His Mates (London, 1590).

39. Bancroft, "Sermon," pp. 3, 40-41. Religion should be considered only by those "well experienced and exercised" in it. Bancroft recycled these words four years later in his A Survey of the Pretended Holy Discipline (London, 1593), p. 154. See also Dangerous Positions, p. 46.

40. Bancroft, Dangerous Positions, p. 32.

41. “... euerie stage Plaier made a iest of him, and put him cleane out of countenance" in Martins Month Minde, sig. E4r, noted by Joseph Black, “The Rhetoric of Reaction: The Martin Marprelate Tracts (1588-89), Anti-Martinism, and the Uses of Print in the Early Modern Era," in The Sixteenth Century Journal 28 (1997), pp. 707-25, p. 715. Black provides the fullest description of the Anti-Martinist campaign in its English context: Black, ed., The Marprelate Tracts (Cambridge: Cambridge University Press, 2008), pp. lvi-lxxiv; Patrick Collinson, "Antipuritanism," in The Cambridge Companion to Puritanism, ed. John Coffey and Paul C. H. Lim (Cambridge: Cambridge University Press, 2008), pp. 19-33; Sarah Knight, "Flat Dichotomists and Learned Men: Ramism in Elizabethan Drama and Satire," in Ramus, Pedagogy and the Liberal Arts: Ramism in Britan and the Wider World, ed. S. Reid and E. A. Wilson (Farnham: Ashgate, 2011), pp. 47-67. See also A. H. Williamson, "The Nation Epidemicall: Scoto-Britannus to Scoto-Polonus," in Britain and Poland-Lithuania: Contact and Comparisons from the Middle Ages to 1795, ed. R. Unger (Leiden: Brill, 2008), pp. 287-304; A. H. Williamson, “'A Pill for Pork-Eaters': Ethnic Identity, Apocalyptic Promises, and the Strange Creation of the Judeo-Scots," in R. B. Waddington and A. H. Williamson, eds., The Expulsion of the Jews: 1492 and After (New York: Garland, 1994), pp. 237-58. 
42. Nashe, Martins Months Minde, sig. F2v. That Machiavellian trick might "bring them [the bishops] in hatred with the credulous multitude ... but take heede of it for it asketh vengeance."

43. tum diligentius libellum Buchanani de Jure Regni, quam Calvini Institutiones lectitabant. John Spottiswoode, sometime 1590s radical but subsequently the archbishop of St. Andrews, made the comment specifically in reference to the late 1596 abortive coup d'etat. Spottiswoode, Refutatio libelli de regimine Ecclesiae Scoticanae (London, 1620), p. 66 (marginal note). We are most grateful to Jamie Reid Baxter for drawing our attention to Spottiswoode's remark and providing a translation. Bancroft's preoccupation with Buchanan emerges in most of his writings and notably in the queries he sent north about the Scottish regime. Calderwood, vol. 5, p. 81.

44. Miscellany of the Wodrow Society, p. 493; NA: SP 52/62/20; McGinnis and Williamson, British Union, pp. 48, 157. This passage from the Miscellany has been cited continuously since Gordon Donaldson first brought it to attention in 1941. The tradition of abuse and complaint that it initiated has not been similarly recognized. Donaldson, "The Attitude of Whitgift and Bancroft to the Scottish Church," in Transactions of the Royal Historical Society, $4^{\text {th }}$ series, 24 (1942), pp. 95-115, p. 109, read 10 May 1941. A redaction of the letter to Elizabeth appears in Calderwood which gives the passage as: "they ceasse not ... to make our discipline rediculous in the eyes of men, by scoffing us in their stage playes." History, vol. 5, pp. 73-77, p. 76.

45. Miscellany of the Wodrow Society, pp. 493. See Williamson, Scottish National Consciousness, pp. 48-49, 56-57, 133-38, and passim.

46. Nashe, An Almond for a Parrat (London, 1590), E2r-v. In a similar way Bancroft would slyly link Buchanan's De jure regni and civic society with the primitive Irish. Bancroft, Dangerous Positions, pp. 30-31. See below.

47. Nashe, Pierce Penilesse (London, 1592), A3v.

48. Nashe, Pierce Penilesse, sig. B2r-v. Nashe unmistakably intends Essex when he further comments that "hee would bee seen amongst Caualiers and braue courtiers" and "should take vppe a scornfull melancholy in his gate and countenance, and talke as though our common welth were but a mockery of gouernment and Maiestrates fooles, who wrong him in not looking into his deserts, not imploying him in State matters, and that if more regard were not had of him very shortly, the whole Realme should haue a misse of him, \& he would go (I [= aye] mary would he) where he should be more accounted." 
49. Nashe, Pierce Penilesse, sig. C4v. Such passages might easily be excised and inserted into Paul Hammer's The Polarization of Elizabethan Politics: The Political Career of Robert Devereux, Second Earl of Essex, 1587-1597 (Cambridge: Cambridge University Press, 1999), pp. 90, 93.

50. Nashe, Pierce Penilesse, sig. G4v. The identities of the various figures in the parable have been much debated. But the bear who "went into the woods all melancholie, and died for pure anger" is surely the late earl of Leicester (sig. H1r). Essex had emerged Leicester's clear successor, and could only be damaged by contempt for his predecessor.

51. Nashe, Pierce Penilesse, sigs. C1v-C2r. After connecting Scotland and Denmark, Nashe goes on to speak of the "light vnconstant multude" dancing after "a blind piper" in preference to true oracles, echoing the Celtic canard in An Almond (H1r).

52. Nashe, Pierce Penilesse, sigs. H1v-I3r. Nashe is exercised to refute unnamed "Mathematitions abroad" who see devils and the satanic as ethical concepts rather than physical realities (B3v, G1v, G2v, H1v-H2v, and passim).

53. Nashe's odd jeremiad against commerce-corrupted London, Christs Teares over Ierusalem (London, 1594), clearly indicates his belief in the workings and physical reality of Satan and his demons. It takes the reality of witchcraft as a given (e.g., pp. 58, 88). See also The Terrors of the Night (London, 1594) and Charles Nicholl, "Nashe, Thomas (bap. 1567, d. c.1601)," Oxford Dictionary of National Biography, Oxford University Press, 2004; online edn, Jan 2008 [http://www.oxforddnb.com/ view/article/19790, accessed 8 January 2012].

54. Nashe may have made an oblique reference to News from Scotland when he remarks: "I bring Pierce Penilesse to question with the diuel as a yoong nouice would talke with a great trauailer; who carrieng an Englishmans appetite to enquire of news, will be sure to make what vse he maie, and not leaue anie thing vnaskt" (Pierce Penilesse, sig. I3r).

55. Axton, "Summer's Last Will and Testament: revels' end," in The Reign of Elizabeth I: Court and Culture in the Last Decade, ed. J. Guy (Cambridge: Cambridge University Press, 1995), pp. 258-73, p. 270.

56. Charles Nicoll, “Thomas Nashe," ODNB. Although Bancroft served as the point man (and lightning rod) for the court-episcopal offensive, the effort was probably more coordinated than appears evident today. Archbishop Whitgift had immediately secured the publication of Bancroft sermon and possibly his appointment to preach at Paul's Cross as well. See Morrissey, p. 209. 
57. Black, Marprelate, pp. lvi-lxxiv; Collinson, "Antipuritanism"; Collinson, "Ecclesiastical Vitriol: Religious Satire and the Invention of Puritanism," in The Reign of Elizabeth I: Court and Culture in the Last Decade, ed. J. Guy (Cambridge: Cambridge University Press, 1995), pp. 150-170; and Wormald, pp. 150-70, 171-91.

58. Bancroft, Dangerous Positions, pp. 30-31.

59. Laws of Ecclesiastical Polity, III.11.16.

60. Burgess, Politics of the Ancient Constitution (Basingstoke: Macmillan, 1992), pp. 18, 86, 100, 102, 103.

61. Recently Burgess has gone on to argue that "ancient constitutionalism" and the appeal to "fundamental law" in England arose not as an effort to resist authoritarian monarchy, but specifically to combat Anglo-Scottish union, for "1603 threatened to break the bonds between the English nation and its past." See Glenn Burgess, "Pocock's History of Political Thought: The Ancient Constitution in Early Stuart England," in The Political Imagination in History: Essays Concerning J. G. A. Pocock, ed. D. N. DeLuna (Baltimore: Owlworks, 2006), pp. 175-208, p. 188 and more generally 184-208.

62. The Tudor "monarchical republic," famously proposed by Patrick Collinson, shrivelled as "citizen" became coterminous with "subject," and "patriot" came to imply dutiful obedience. See Collinson, "The Monarchical Republic of Queen Elizabeth I," in Bulletin of the John Rylands Library 69 (1986-87), pp. 394-424; "De Republica Anglorum; or, History with the Politics Put Back," in Elizabethan Essays (London: Hambleton Press, 1994), pp. 1-28; “The Elizabethan Exclusion Crisis and the Elizabethan Polity," Proceedings of the British Academy 84 (1994), pp. 51-92; reprinted in Collinson, This England: Essays on the English Nation and Commonwealth in the Sixteenth Century (Manchester: Manchester University Press, 2011), pp. 61-97. See also McGinnis and Williamson, The British Union, pp. 24-53; Williamson, "The Rise and Decline of the British 'Patriot." 